\title{
CYTOTOXIC EFFECT OF PEPTIDE FUNCTIONALIZED SILVER NANOPARTICLES SYNTHESIZED FROM ALOIN ON BREAST CANCER CELL LINE
}

\author{
LEEMA ROSE A, VIDHYA S, JANEETA PRIYA F*, SABEENA ASHIFA J
}

\author{
Department of Chemistry, Holy Cross College, Affiliated to Bharathidasan University, Tiruchirappalli, Tamil Nadu, India. \\ Email: janeetapriya@gmail.com
}

Received: 03 August 2018, Revised and Accepted: 09 October 2018

\section{ABSTRACT}

Objective: The aim of the present study is to synthesize the silver (Ag) nanoparticle using Aloin with a focus on its antibacterial, antioxidant, and anticancer activity.

Methods: The silver nanoparticles were synthesized using Aloin and were determined by UV-Visible spectrum. It was further characterized by scanning electron microscope (SEM), zeta potential, and dynamic light scattering (DLS). The Fourier transform infrared analysis was also carried out for the Aloin.

Results: The UV-Visible absorption spectrum of the synthesized silver nanoparticles has shown the absorption peak at 439nm which proves the formation of silver nanoparticles in the solution. The SEM analysis revealed that the Ag nanoparticles were spherical in shape. The IR spectra showed that there are 6 functional groups are present in Aloin extract. The synthesized nanoparticles are found to be highly stable with an average particle size of $130.7 \mathrm{~nm}$ which was confirmed by zeta potential and DLS analysis. The synthesized nanoparticles had a good antibacterial and antioxidant activity. It shows a very good cytotoxic effect against breast cancer cell line.

Conclusion: The present study suggests that the synthesis route is free from the requirements such as high energy, extended preparation time, and special equipments and thus can be used for large-scale synthesis in food industries for food preservation and these Ag nanoparticles can be used for its therapeutic purposes for developing a new drug against cancer.

Keywords: Silver nanoparticles, Aloin, UV, Scanning electron microscope, Fourier transform infrared, Zeta potential, DLS, Antioxidant activity, Antibacterial activity, Anticancer activity.

(C) 2019 The Authors. Published by Innovare Academic Sciences Pvt Ltd. This is an open access article under the CC BY license (http://creativecommons. org/licenses/by/4. 0/) DOI: http://dx.doi.org/10.22159/ajpcr.2019.v12i2.28836

\section{INTRODUCTION}

Nanoscience and nanotechnology are the investigation and utilization of extremely small things and can be worn across all the other science fields, such as chemistry, biology, physics, materials science, and engineering [1].

Current research in inorganic nanomaterials having good therapeutic properties has opened a new era in medicinal fields. Nowadays, the reinforcement of potent green methods for the synthesis of inorganic nanoparticles has become an exceeding intention of the researchers. The biosynthesis of nanoparticles has been designed as a profitable and environmentally friendly alternative to chemical and physical methods.

Silver nanoparticles have fascinated and demandable research of interest in the field of nanotechnology, due to its distinct properties such as catalytic activity, chemical stability, surface-enhanced Raman scattering, good conductivity, and antimicrobial activity [2].

The nanoparticle synthesis using plant extracts is highly fruitful, and hence can be used as a commercial and valuable alternative for the massive production of metal nanoparticles. In general, plant extracts may act both as reducing and capping agents in the synthesis of nanoparticles. The essential and analytical roles of plants in bio-based protocols for metal nanoparticle production and the green synthesis of metal nanoparticles using Aloin have been discussed.

In this present study, Aloin has been used which was extracted from Aloe barbadensis miller. It also contains salicylic acid that possesses anti-inflammatory and antibacterial properties, and it also contains 75 potentially active constituents, especially vitamins, enzymes, minerals, sugars, lignin, saponins, salicylic acids, and amino acids [3-5]. The current investigation focused on using the sample Aloin to synthesize the silver nanoparticles at various experimental conditions and thereby improving the attention of plant source and involving green chemistry for the synthesis of other nanoparticles as future research.

\section{METHODS}

\section{Chemicals}

Silver nitrate, potassium bromide, ethyl acetate, agar-agar medium, and methanol were obtained from Eswar Scientific and Co., Tiruchirappalli. All the chemicals purchased were of analytical grade.

\section{Collection and preparation of Aloin extract}

Fresh leaves of $A$. barbadensis miller were collected from Kulumani village in Tiruchirappalli. The collected leaves were washed thoroughly with distilled water, and ethyl acetate solution and its extract were collected in a brown bottle and stored in the refrigerator. The Aloin was further extracted using Soxhlet extraction method.

\section{Soxhlet extraction method}

The collected sample is placed in a thimble holder. The thimble containing the material is then placed in the Soxhlet extractor. Here, we are using ethyl acetate (LR grade) as the solvent which was loaded into the round bottom flask was heated at reflux. Moreover, the cold water is continuously passed through the condenser at the inlet and removed out at the outlet of the pipe. As the solvent gets boiled, its vapors rise up and is condensed by the condenser. The condensed solvent then fills up the thimble. After it is filled with enough amount of solvent, it automatically siphons back down into the container of organic solvent carrying the extracted active ingredient into the bulk liquid. This process takes place over and over again until all the sample was extracted from the $A$. barbadensis miller plant. The sample obtained from the soxhlet extraction was then stored in an airtight container at $4^{\circ} \mathrm{C}$ for further analysis [6]. 
Synthesis of silver nanoparticles

About $2 \mathrm{mM}$ silver nitrate solution was prepared by weighing $0.1698 \mathrm{~g}$ of silver nitrate accurately and dissolved in $50 \mathrm{ml}$ of deionized water. The prepared silver nitrate solution was covered with an aluminum foil to prevent the photochemical reaction. For the synthesis of silver nanoparticles, $1 \mathrm{ml}$ of the silver nitrate solution was taken in an Eppendorf. To this, $50 \mu \mathrm{l}$ of the stock solution was gradually added in a dropwise manner without any contamination. After gradual addition, the solution is irradiated in the microwave oven at $60^{\circ} \mathrm{C}$. Within $30 \mathrm{~s}$, the silver nanoparticles were formed without any agglomeration, which indicates that the synthesized nanoparticles were highly stable. The formation of the silver nanoparticles was confirmed by the gradual color change of the reaction mixture of transparent yellow to dark reddish brown.

\section{RESULTS AND DISCUSSION}

\section{Visual observation}

An aqueous solution of $2 \mathrm{mM}$ silver nitrate was used for the synthesis of silver nanoparticles. For the synthesis of silver nanoparticles, about $50 \mu \mathrm{l}$ of the sample was added to $1 \mathrm{ml}$ of $2 \mathrm{mM}$ silver nitrate solution. This was then irradiated at $60^{\circ} \mathrm{C}$ in a microwave oven for $30 \mathrm{~s}$. The color of the extract gradually changes from transparent yellow to dark

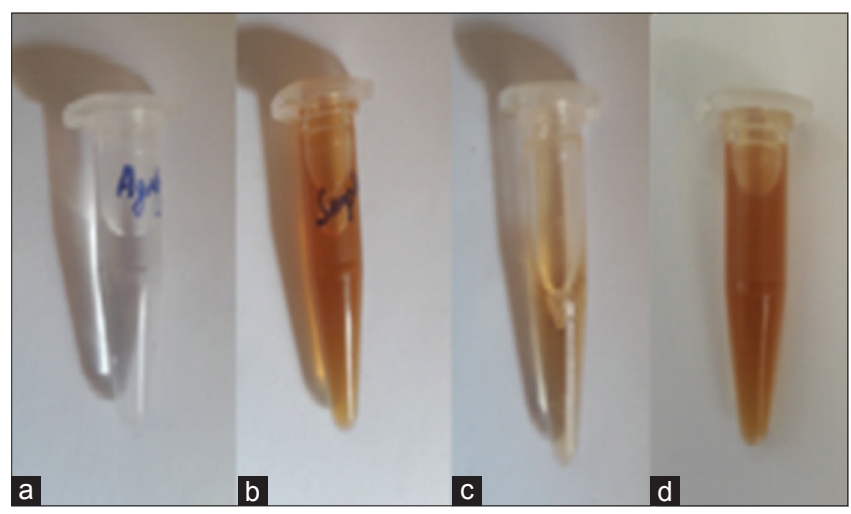

Fig. 1: (a) 2 mM silver nitrate solution, (b) Aloin extract, (c) color change after the addition of Aloin extract, (d) color change after microwave irradiation reddish brown. The color of the solution remains the same for more than 20 days at $4^{\circ} \mathrm{C}$. Then, the reaction mixture was centrifuged at $20,000 \mathrm{rpm}$ for $20 \mathrm{~min}$ to obtain a pellet which was used for further study. The supernatant was discarded, and the pellet was dissolved in double distilled water and stored at $4^{\circ} \mathrm{C}$ for further analysis. The color change of the solution from transparent yellow to dark reddish brown was shown in Fig. 1.

\section{UV-visible spectroscopy}

The bioreduction of nanoparticles was monitored periodically by UVvisible spectroscopy. Figs. 1-4 shows the absorption peak at $439 \mathrm{~nm}$ which proves the formation of silver nanoparticles in the solution.

The initial pale yellow color of the solution turned dark reddish brown. This shift in color is due to the surface plasmon resonance (SPR) band. This property is observed in the silver due to the presence of free electrons [7].

\section{Fourier transform infrared (FTIR) spectroscopy}

The FTIR measurement was done to find out the biomolecules present in the plant extract that is responsible for capping and reducing agent for the synthesis of silver nanoparticles. This technique is used to estimate the purity of a sample and is highly anticipated for identifying the base polymer composition, additives, and organic contaminants [8].

The infrared spectrum of the plant extract as shown in Fig. 3 was in the wavelength range of $686.87-3432.77 \mathrm{~cm}^{-1}$, and there were six functional groups are present (Table 1).

\section{Scanning electron microscope (SEM)}

The SEM analysis was employed for the characterization of size, shape, and morphology of the synthesized nanoparticles [9]. As the size and morphology of particles were characterized using SEM, Fig. 4 indicates that the synthesized silver nanoparticles were spherical in shape and the details regarding applied voltage, magnification used and size of the contents of the images was implanted on the images.

\section{Zeta potential analysis}

To study the stability of the synthesized nanoparticles, measurement of zeta potential was carried out as the stability is extremely important for many applications (Figs. 5-11).

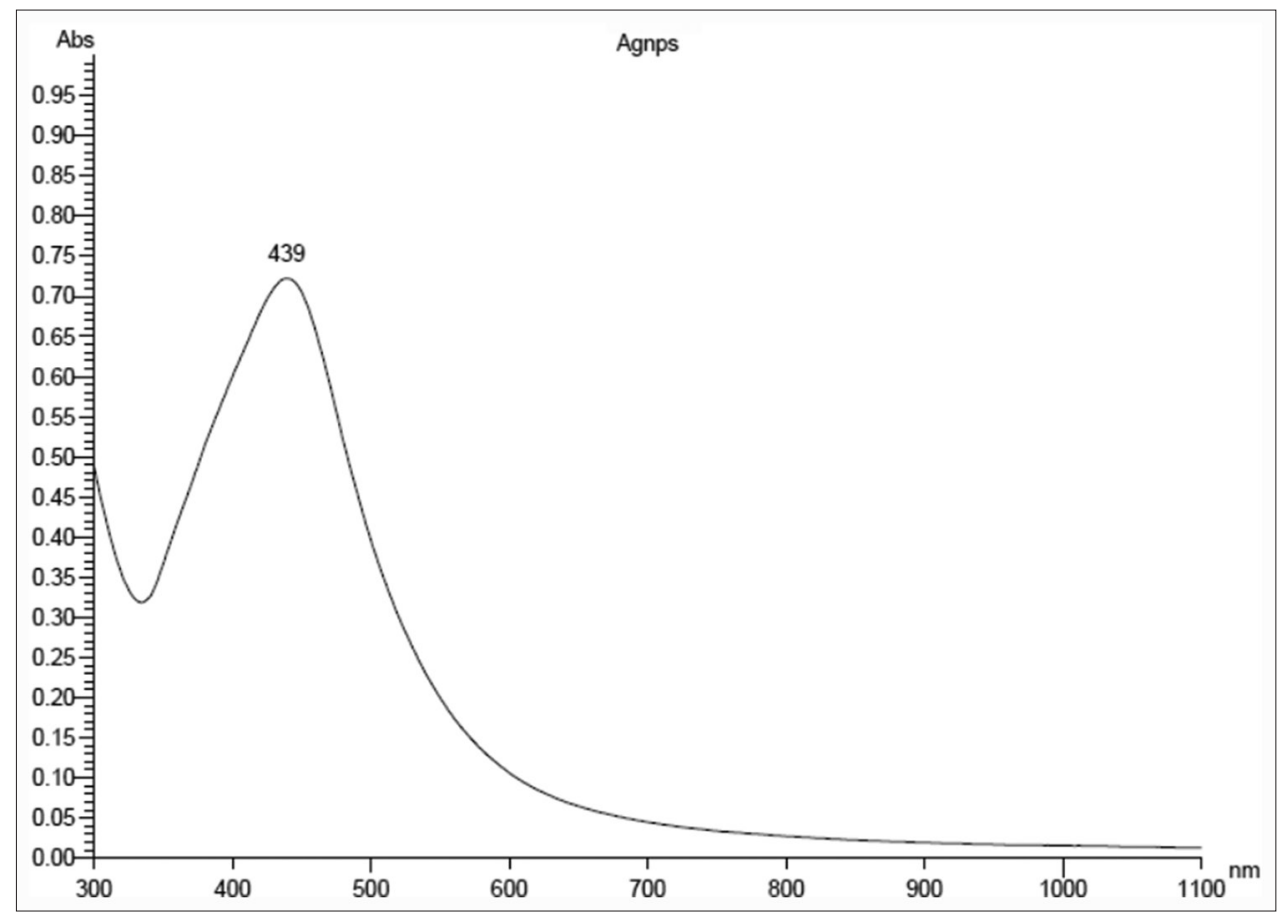

Fig. 2: UV-visible spectrum of silver nanoparticles 


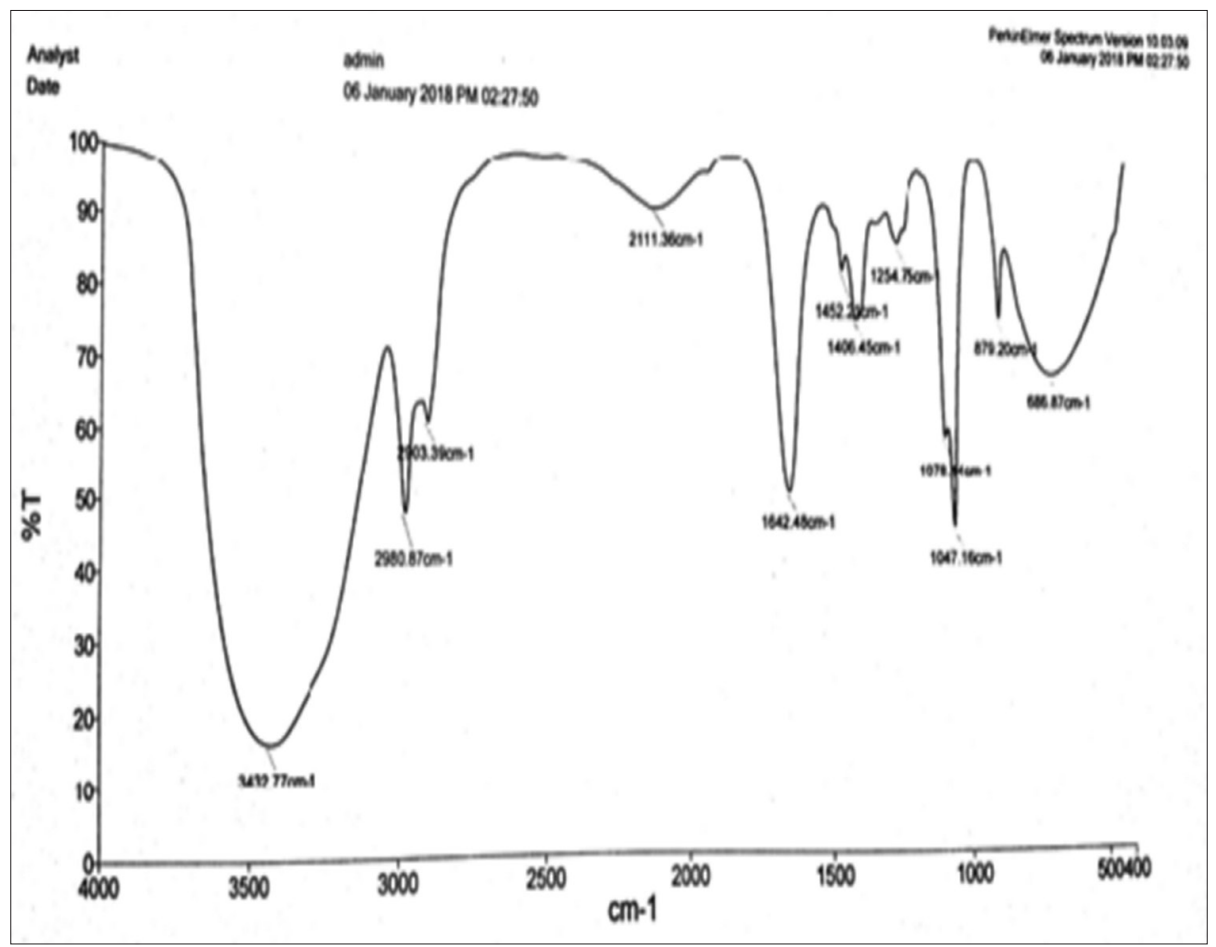

Fig. 3: Infrared spectrum of Aloin extract

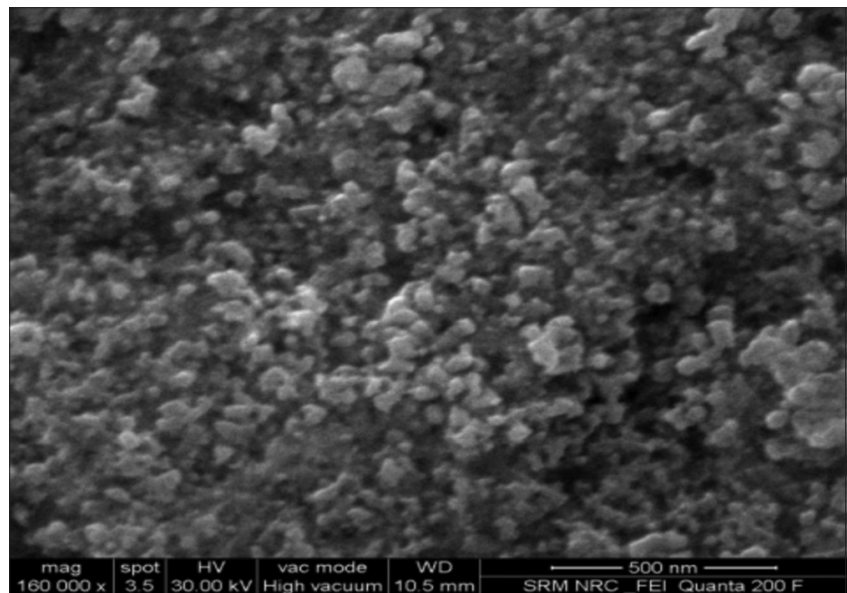

Fig. 4: Scanning electron microscope images of silver nanoparticles

When particles in a colloidal system have large negative or positive zeta potential, repulsion forces between them prevents aggregation. In contrast, when nanoparticles present low surface charges, the absence of repulsive forces favors agglomeration. In this context, nanoparticle suspensions with zeta potential values $>+25 \mathrm{mV}$ or $<-25 \mathrm{mV}$ usually form high stable suspensions [10]. The value of zeta potential for synthesized silver nanoparticles is $-19.1 \mathrm{mV}$ which indicates that the synthesized nanoparticles are highly stable.

\section{Dynamic light scattering (DLS) analysis}

The present study used DLS to evaluate the size distribution of the synthesized silver nanoparticles in aqueous solution.

The results of DLS showed silver nanoparticles with an average particle size of $130.7 \mathrm{~nm}$.

Due to its smaller size and high stability, these nanoparticles are highly recommended in medicinal fields especially for the treatment of cancer [11].
Table 1: Functional compounds of Aloin analyzed using FTIR

\begin{tabular}{lll}
\hline Wavelength $\left(\mathbf{c m}^{-1}\right)$ & Vibration type & Functional Group \\
\hline 686.87 & C-H bending & Aromatic \\
879.20 & C-cl stretch & Aromatic acid halide \\
1047.16 & C-O-C stretching aliphatic Ether \\
1078.14 & C-O-C stretching aliphatic Secondary alcohol \\
1254.75 & C-O-C stretching & Ether \\
1406.45 & C-O stretching & Phenols \\
1452.21 & Ring aromatic stretch & Aromatic \\
1642.48 & C-H stretching & Aldehyde \\
2111.36 & C=C stretching & Monosubstituted \\
2903.39 & C-H stretching & Aldehyde \\
2980.87 & C-H stretching & Methylene \\
3432.77 & OH stretching & Alcohol \\
\hline
\end{tabular}

FTIR: Fourier transform infrared

Table 2: Antibacterial activity of the synthesized silver nanoparticles

\begin{tabular}{|c|c|c|c|}
\hline \multirow[t]{3}{*}{ Sample } & \multirow[t]{3}{*}{$\begin{array}{l}\text { Concentrations } \\
(\mu \mathrm{g} / \mathrm{ml})\end{array}$} & \multicolumn{2}{|c|}{$\begin{array}{l}\text { Organisms/zone of } \\
\text { inhibition }(\mathrm{mm})\end{array}$} \\
\hline & & \multicolumn{2}{|c|}{$\begin{array}{l}\text { Aqueous extract of silver } \\
\text { nanoparticles }\end{array}$} \\
\hline & & $\begin{array}{l}\text { Pseudomonas } \\
\text { aeruginosa }\end{array}$ & $\begin{array}{l}\text { Staphylococcus } \\
\text { aureus }\end{array}$ \\
\hline Silver & 30 & 0 & 0 \\
\hline \multirow{4}{*}{ Nanoparticles } & 60 & 0 & 0 \\
\hline & 90 & 7 & 7 \\
\hline & 120 & 8 & 7 \\
\hline & 150 & 9 & 7 \\
\hline Methanol & $10 \mu \mathrm{l} / \mathrm{disc}$ & 0 & 0 \\
\hline
\end{tabular}

Antibacterial activity

The results of the antibacterial activity of the synthesized silver nanoparticles were tested against pathogens by disk diffusion method are shown in Table 2. 


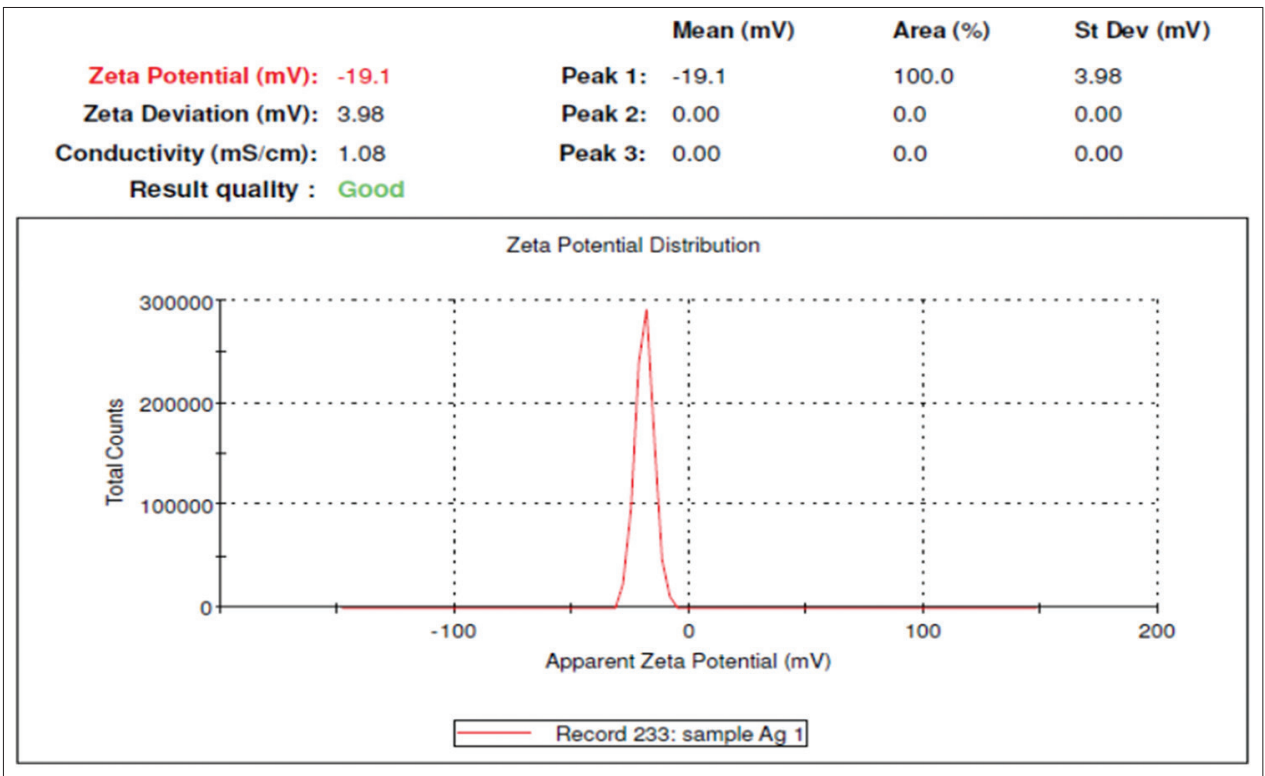

Fig. 5: Zeta potential analysis of synthesized silver nanoparticles

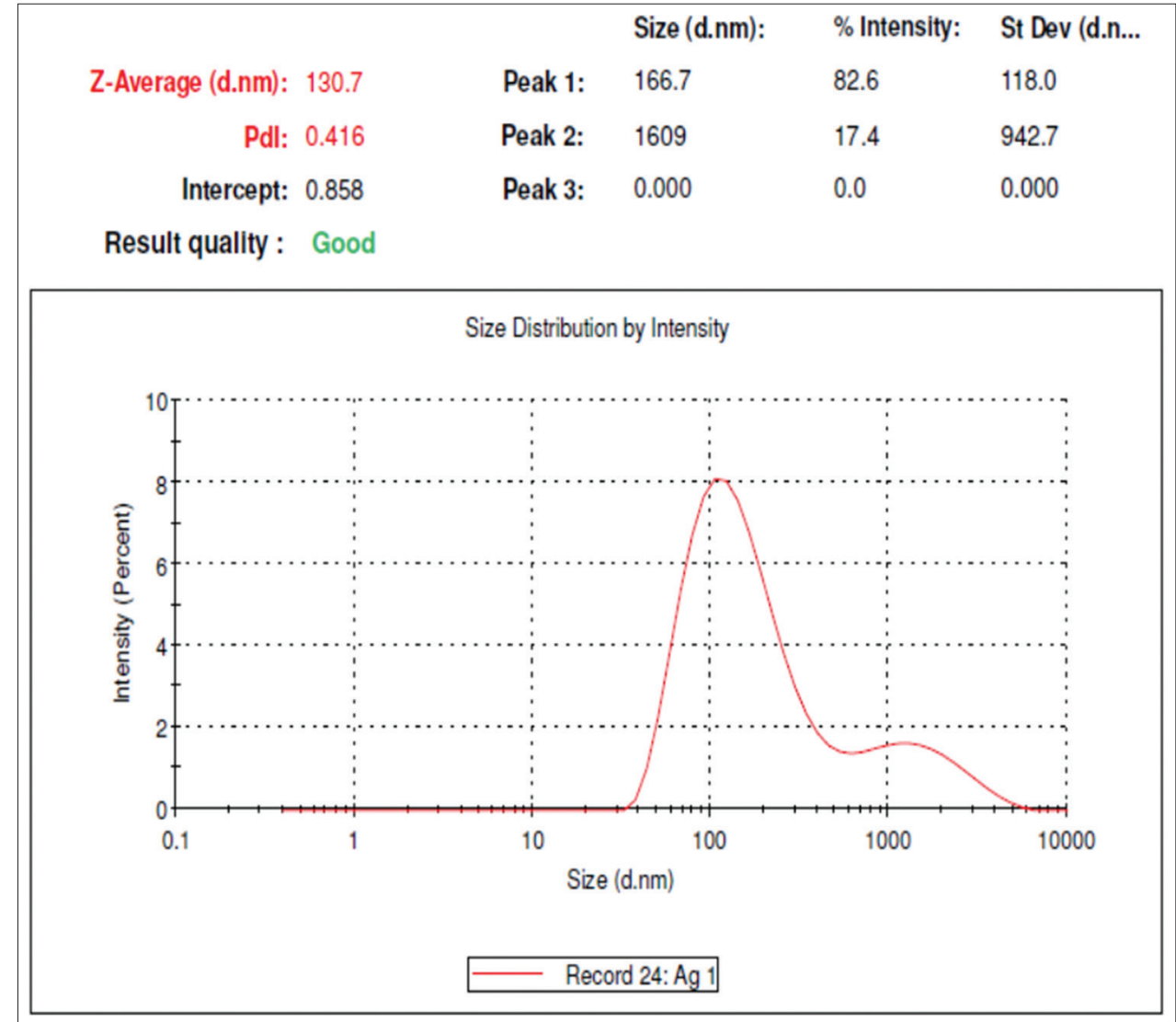

Fig. 6: Size distribution analysis by dynamic light scattering

Table 3: The total antioxidant activity of Aloin extract

\begin{tabular}{lll}
\hline Concentrations $(\mu \mathrm{g})$ & $\begin{array}{l}\mu \mathrm{g} \text { equivalent } \\
\text { to AA B1 }\end{array}$ & $\begin{array}{l}\mu \mathrm{g} \text { equivalent } \\
\text { to AA BHA }\end{array}$ \\
\hline 10 & 7.99 & 12.68 \\
50 & 13.11 & 19.96 \\
100 & 22.59 & 38.15 \\
\hline
\end{tabular}

BHA: Butylated hydroxyanisole
The silver nanoparticles showed growth inhibitory activity against Pseudomonas aeruginosa ( $9 \mathrm{~mm}$ ) and Staphylococcus aureus $(7 \mathrm{~mm})$ at concentration $150 \mu \mathrm{g} / \mathrm{ml}$.

At concentration $120 \mu \mathrm{g} / \mathrm{ml}$, the synthesized nanoparticles exhibited the antibacterial activity against $P$. aeruginosa $(8 \mathrm{~mm})$. However, the silver nanoparticles showed better inhibitory actions against pathogens at a concentration of 90,120 , and $150 \mu \mathrm{g} / \mathrm{ml}$ than at lower concentration. 
Table 4: Raw data absorbance values at $570 \mathrm{~nm}$ and percentage growth inhibition

\begin{tabular}{lllll}
\hline Sample & $\mathbf{1}$ & $\mathbf{2}$ & $\mathbf{3}$ & $\mathbf{5}$ \\
\hline A & 5PL1:1 1000 Ag-NP & SPL1:1 1000 Ag-NP & SPL1:1 1000 Ag-NP & Untreated control \\
B & SPL1:2 300 Ag-NP & SPL1:2 300 Ag-NP & SPL1:2 300 Ag-NP & Tntreated control \\
C & SPL1:3 100 Ag-NP & SPL1:3 100 Ag-NP & SPL1:3 100 Ag-NP & TO \\
D & SPL1:4 30 Ag-NP & SPL1:4 30 Ag-NP & SPL1:4 30 Ag-NP & TO \\
E & SPL1:5 10 Ag-NP & SPL1:5 10 Ag-NP & SPL1:5 10 Ag-NP & Untreated control \\
F & SPL1:6 3 Ag-NP & SPL1:6 3 Ag-NP & SPL1:6 3 Ag-NP & Untreated control \\
\hline
\end{tabular}

Table 5: \% Cytotoxicity

\begin{tabular}{llllll}
\hline Sample & $\mathbf{1}$ & $\mathbf{2}$ & $\mathbf{3}$ & $\mathbf{4}$ & $\mathbf{5}$ \\
\hline A & 165.4 & 165.2 & 165.4 & -14.7 & \\
B & 164.4 & 165.1 & 164.7 & -7.3 & \\
C & 144.9 & 150.4 & 148.2 & 9.3 & \\
D & 92.8 & 95.5 & 95.0 & 6.1 & \\
E & 46.0 & 44.5 & 47.5 & 0.5 & \\
F & -10.0 & 4.4 & -12.2 & 6.2 & \\
\hline
\end{tabular}

As the concentration of extracts increased from 30 to $150 \mu \mathrm{g} / \mathrm{ml}$, the inhibitory actions of the plant extracts increased toward all the strains used in this study [12].

\section{Antioxidant activity}

\section{Methodology}

Various concentrations of samples $(10 \mu \mathrm{g}, 50 \mu \mathrm{g}$, and $100 \mu \mathrm{g})$ were taken and $1.9 \mathrm{ml}$ of reagent solution ( $0.6 \mathrm{M}$ sulfuric acid, $28 \mathrm{mM}$ sodium phosphate, and $4 \mathrm{mM}$ ammonium molybdate) were added in a series of test tubes. The tubes were incubated at $95^{\circ} \mathrm{C}$ for $90 \mathrm{~min}$ and allowed to cool. The absorbance of each of the aqueous solution was measured at $695 \mathrm{~nm}$ against a blank. Antioxidant capacities are indicated as equivalents of ascorbic acid. Ascorbic acid equivalents were determined using the standard graph of ascorbic acid. Butylated hydroxyanisole (BHA) was used as reference standard (Table 3) [13,14].

\section{Peptide-based silver nanoparticle and its anticancer activity}

The test item AgNP-Peptide was tested against the MCF-7 cell line. The test item concentrations ranging from 1000, 300, 100, 30, 10, and $3 \mu \mathrm{g} / \mathrm{ml}$ in the semi-logarithmic range was used to assess the growth inhibition properties of the test compound. Each concentration was performed in quadruplicate, and cumulative variation was maintained $<20 \%$ between the data points.

The test compound is showing a cytotoxic effect on the tested cell line $[15,16]$. The IC ${ }_{50}$ value for the AgNP-peptide is showing at $22 \mathrm{ug} / \mathrm{ml}$. Results and raw data have been illustrated in the following Tables 4 and 5, graph.

It has been found that the silver nanoparticles that were prepared from Aloin show a good cytotoxic effect against the MCF-7 cell line [17]. However, those nanoparticles only minimize the affected cells, but the peptide linked silver nanoparticles not only destroys but also prevents the cancer cells.

\section{CONCLUSION}

The green synthesis of silver nanoparticles was successfully carried out through microwave assisted green synthesis using silver nitrate as the precursor, and the Aloin extracted from A. barbadensis miller is used as the reducing agent.

The SPR band at $439 \mathrm{~nm}$ in the UV-visible spectrum clearly indicates the formation of silver nanoparticles. The FTIR analysis confirmed the list of compounds that are present in the Aloin. The sample that was extracted from the plant, A. barbadensis miller showed a good antioxidant property. The SEM analysis showed that the synthesized silver nanoparticles were spherical in shape. The zeta potential analysis

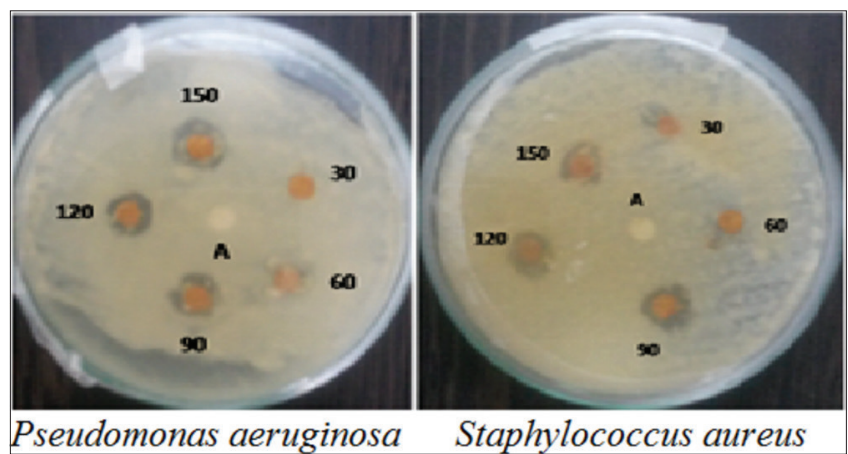

Fig. 7: Antibacterial activity of the synthesized silver nanoparticles

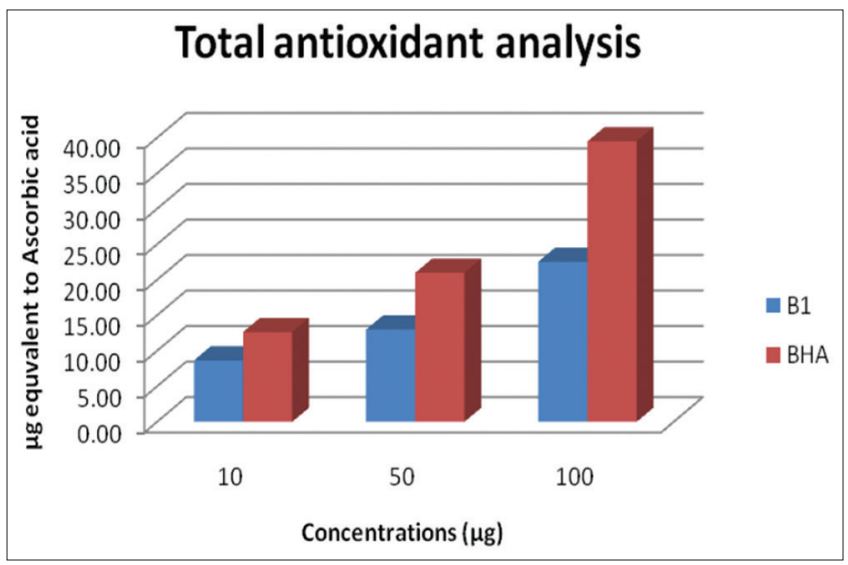

Fig. 8: B1 and butylated hydroxyanisole assay

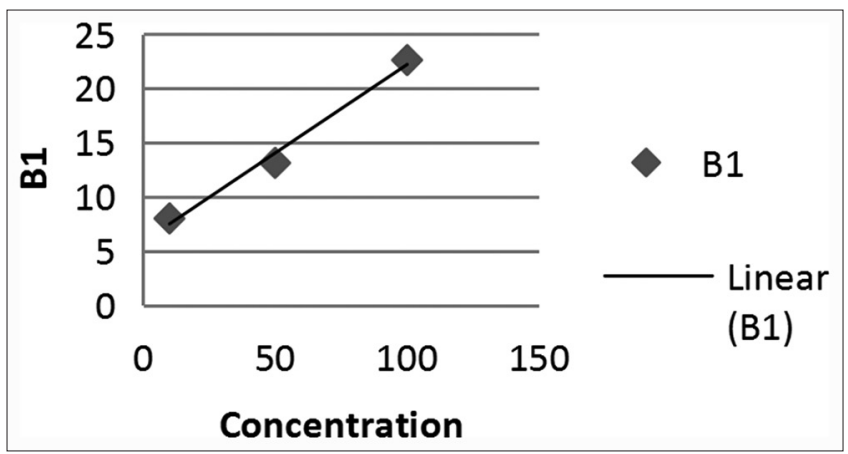

Fig. 9: Graphical representation of the antioxidant activity of Aloin extract

indicates that the synthesized nanoparticles had good stability. The results of DLS analysis showed that the synthesized nanoparticles had an average particle size of $130.7 \mathrm{~nm}$. The antibacterial studies revealed that they are highly toxic against $P$. aeruginos and $S$. aureus. The anticancer activity of peptide-based silver nanoparticle is amazing; 


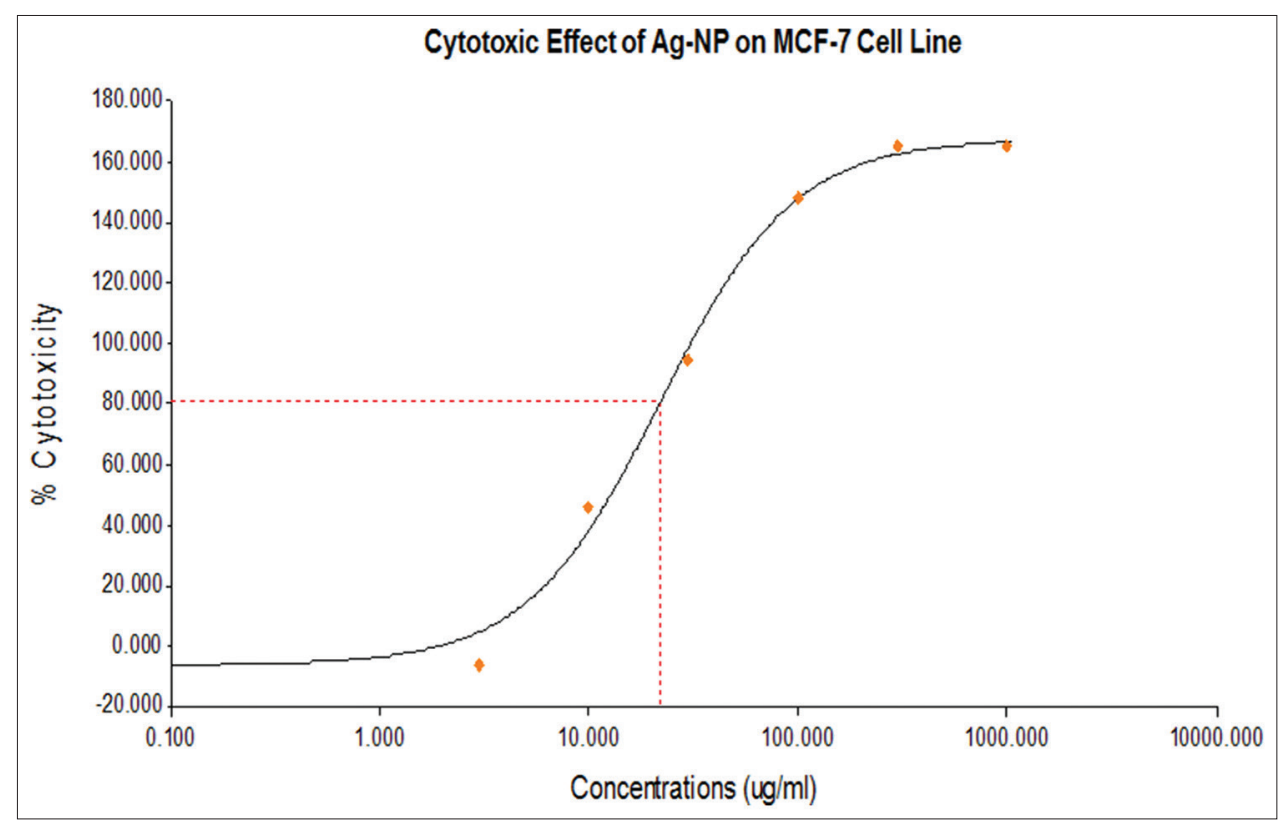

Fig. 10: Graphical representation of the cytotoxic effect of synthesized silver nanoparticle peptide on MCF-7 cell line

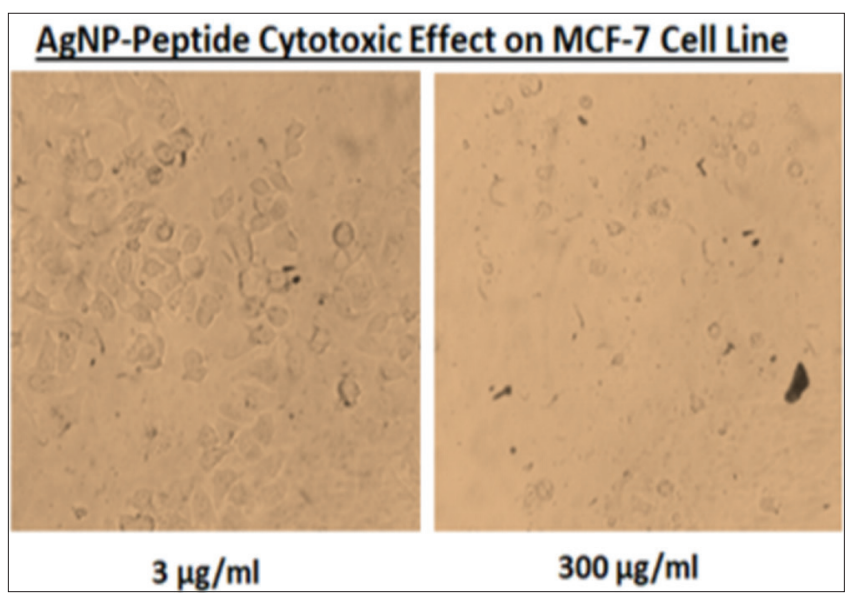

Fig. 11: Cytotoxic effect of synthesized silver nanoparticle peptide on MCF-7 cell line

it is capable to kill the cancer cells. The test compound is showing the cytotoxic effect on the breast cancer cell line.

\section{ACKNOWLEDGMENT}

The authors would like to thank the PG and Research Department of Chemistry, Holy Cross College, Trichy, for providing the necessary facilities to conduct this research work.

\section{AUTHOR'S CONTRIBUTION}

Thanks to SRM University - Kattankulathur, Nano Facility Center Chennai, for their instrumentation support.

\section{CONFLICTS OF INTEREST}

The authors declare that they have no conflicts of interest.

\section{REFERENCES}

1. Allhoff F, Lin P, Moore D. What is Nanotechnology and Why Does it Matter? From Science to Ethics. Hoboken, New Jersey: John Wiley and Sons; 2010. p. 3-5.
2. Prabhu S, Poulose EK. Silver nanoparticles: Mechanism of antimicrobial action, synthesis, medical applications and toxicity effects. Int Nano Lett 2012;2:1-10.

3. Atherton P. Aloe vera revisited. Br J Phytother 1998;4:76-83.

4. Shelton RM. Aloe vera Its chemical and therapeutic properties. Int J Dermatol 1991;30:679-83.

5. Atherton P. The Essential Aloe vera: The Actions and the Evidence. $2^{\text {nd }}$ ed. Oxford: Mill Enterprises; 1997.

6. Nounagnon MS, Dah-Nouvlessounon D, N'tcha C, Legba B, Babamoussa F, Adjanohoun A, et al. Phytochemistry and biological activities of Crateva adansonii extracts. Int J Pharm Pharm Sci 2018;10:62-7.

7. Choudhary RS, Bhamare NB, Mahure BV. Bioreduction of silver nanoparticles using different plant extracts and its bioactivity against E. coli and A. niger. IOSR J Agric Vet Sci 2014;7:7-11.

8. Zhang XF, Liu ZG, Shen W, Gurunathan S. Silver nanoparticles: Synthesis, characterization, properties, applications, and therapeutic approaches. Int J Mol Sci 2016;17:E1534.

9. Narsih, Kumalaningsih S, Wignyanto, Wijana S. Identification of aloin and saponin and chemical composition of volatile constituents from Aloe vera (L.) Peel. J Agric Food Tech 2012;2:79-84.

10. Duman O, Tunc S. Electro kinetic and rheological properties of Nabentonite in some electrolyte solutions. Microporous Mesoporous Mater 2009;117:331-8.

11. Tomaszewska E, Soliwoda K, Kadziola K, Tkacz-Szczesna B, Celichowski G, Cichomski M, et al. Detection limits of DLS and UVVis spectroscopy in characterization of poly disperse nanoparticles colloids. J Nanomater 2013;2013:1-10.

12. Hajipour MJ, Fromm KM, Ashkarran AA, Jimenez de Aberasturi D, de Larramendi IR, Rojo T, et al. Antibacterial properties of nanoparticles. Trends Biotechnol 2012;30:499-511.

13. Sathisha AD, Lingaraju HB, Prasad KS. Evaluation of antioxidant activity of medicinal plant extracts produced for commercial purpose. E J Chem 2011;8:882-6

14. Arya P. Antioxidant, phytochemical and antibacterial action of Himalayan medicinal herbs Peristrophe bicalyculata Leaves extract against respiratory tract pathogens. Int J Pharm Pharm Sci 2018;10:16-21.

15. Sharma R, Chandan G, Chahal A, Saini RV. Antioxidant and anticancer activity of methanolic extract from Stephania elegans. Int J Pharm Pharm Sci 2017;9:245-9.

16. Lalitha V, Korah MC, Sengottuvel S, Sivakumar T. Antidiabetic and antioxidant activity of resveratrol and Vitamin-C combination on streptozotocin induced diabetic rats. Int $\mathrm{J}$ Pharm Pharm Sci 2015;7:455-8.

17. Chahal A, Saini AK, Chhillar AK, Saini RV. Natural antioxidants as defence system against cancer. Asian J Pharm Clin Res 2018;11:1-7. 